Teresa Famulska

\title{
HARMONISATION OF VAT RATES IN THE EUROPEAN UNION COUNTRIES - THE ACTUAL STATE AND PERSPECTIVES
}

Fiscal solutions belong to the group of basic elements of public finance. Therefore, it is necessary to consider tax related issues while discussing any reform of public finance.

Value Added Tax (VAT) plays a significant role in contemporary fiscal systems. The tax is subject to harmonisation in the European Union ${ }^{1}$. VAT is also the only tax that was used to construct a universal fiscal model to be used in the whole European Union. Implementation of 'the pattern' was regulated by subsequently issued directives - altogether more than twenty. The harmonisation level of numerous VAT technical elements is considerable ${ }^{2}$ (particularly concerning the entity, the subject, the base, the moment a tax liability emerges, the place of taxable transactions, exemptions, special principles of taxation, etc.). With reference to creation of the common market, i.e. abolishment of customs related barriers for the flow of goods in the member countries of the Community, a system of the so-called intra-Community transactions was introduced. The system in question is responsible for functioning of the VAT in compliance with binding principles in the target country. However, much more attention should be still paid to the issue of equalising VAT rates that are applied in the member countries of the European Union. The harmonisation level of the rates in question is deemed to be low.

From the theoretical point of view, only one standard VAT rate to be used in all member countries (the same in the whole European Union) would be the most beneficial solution that would increase effectiveness of the homogeneous common market. In practice, such deep VAT harmonisation has turned out not to be feasible so far. Despite the fact that VAT harmonisation related efforts were undertaken for the first time as early as in $1967^{3}$, some resolutions that referred to the level of rates

J. Głuchowski, Polskie prawo podatkowe, Warsaw, 2006, p. 208.

B. Brzeziński, M. Kalinowski, Prawo podatkowe Wspólnoty Europejskiej, Gdańsk, 2005, p. 89.

I Directive of the Council 67/227/EEC of 11 April 1967. on the harmonisation of legislation of Member States concerning turnover taxes (Journal of Laws - EU Official Journal 1967, L. 71). 
appeared in 1992, in the Council Directive ${ }^{4}$ that came into force on the $1^{\text {st }}$ of January 1993 , i.e. since the homogeneous internal market was introduced. As far as the rates are concerned, it was decided that in each member country only one standard rate was to be in use and its minimal level was to amount to $15 \%$. In case of some goods and services, member countries were also permitted to apply one or two reduced rates that would not go below 5\%. Such a solution was considered transitional and it was supposed to be in force till the end of 1996. In practice, the very transitional nature of the solution in question has been retained. The above principles were firstly prolonged to be still binding till the end of $1998^{5}$, then till the end of $2000^{6}$, whereas all resolutions that referred to reduced rates were decided to be binding indefinitely. Another prolongation of the minimal standard VAT rate amounting to $15 \%$ to be applied in all member countries was made for the period of five years, i.e. 2001$2005^{7}$, and then for another five years, i.e. till the end of $2010^{8}$. The requirement to set a minimal standard VAT rate is met by all member countries (see Table 1). However, it is necessary to note down that there is a considerable difference - amounting to 10 percentage points - between the rates binding in countries of the European Union. Denmark and Sweden are countries where the highest standard VAT rates amounting to $25 \%$ are applied. The lowest rates $(15 \%)$ are enjoyed in Cyprus and Luxemburg. It is assumed that differences between standard rates that are binding in particular member countries should not exceed five percentage points. Such diversification does not generate any disturbances in the way the common market functions, e.g. in case of the so-called trans-border acquisitions. Decreasing the difference in question will be a long lasting process and must be carried out gradually. Difficulties experienced while balancing the amount of the standard rate that would be appropriate for a particular country are clearly confirmed by the analysis of rates that were subsequently applied in countries of the Community 9 . In some countries the rates in question were changed many times (e.g. in Ireland - 11 times, in Holland and in Italy -8 times, in France and in Germany -7 times). It is now necessary to emphasise that a so-called "trial and error approach" is frequently applied to deal with the problem of rates. For instance, France subsequently experienced increasing followed by another increasing, then decreasing, decreasing again, increasing,

4 Directive of the Council 92/77/EEC of 19 October 1992 supplementing the common system of value added tax and amending Directive 77/388/EEC (approximation of VAT rates), (EU Official Journal 1992, L. 316).

5 Directive of the Council 96/95/EC of 20 December 1996 amending the Directive 77/388/EEC with regard to the level of the standard rate of value added tax (EU Official Journal 1996, L. 338).

6 Directive of the Council 1999/49/EC of 25 May 1999 amending the Directive 77/388/EEC on the common system of Vat with regard to the level of the standard rate of VAT (EU Official Journal 1999, L. 139).

7 Directive of the Council 2001/4/EC of 19 January 2001 amending the Directive 77/388/EEC on the common system of VAT, with regard to the length of time during which the minimum standard rate is to be applied, (EU Official Journal2001, L. 22).

8 Directive of the Council 2005/92/EC of 12 December 2005 amending the Directive 77/388/EEC with regard to the length of time during which the minimum standard rate is to be applied (EU Official Journal 2005, L. 345).

9 T. Famulska, Teoretyczne i praktyczne aspekty funkcjonowania podatku od wartości dodanej, Katowice, 2007, pp. 48-49. 
Harmonisation of Vat Rates in the European Union Countries...

increasing once more and finally decreasing again. In case of Denmark, Ireland and Sweden the difference between the highest and the lowest rates applied amounted to even more than ten percentage points.

Table 1. List of VAT rates applied in the Member States (1.01.2008)

\begin{tabular}{|c|c|c|c|c|}
\hline Member States & Super Reduced Rate & Reduced Rate & Standard Rate & Parking Rate \\
\hline Belgium & - & $6 / 12$ & 21 & 12 \\
\hline Bulgaria & & 7 & 20 & \\
\hline Czech Republic & - & 5 & 19 & - \\
\hline Denmark & - & - & 25 & - \\
\hline Germany & - & 7 & 19 & - \\
\hline Estonia & - & 5 & 18 & - \\
\hline Greece & 4.5 & 9 & 19 & - \\
\hline Spain & 4 & 7 & 16 & - \\
\hline France & 2.1 & 5.5 & 19.6 & - \\
\hline Ireland & 4.8 & 13.5 & 21 & 13.5 \\
\hline Italy & 4 & 10 & 20 & \\
\hline Cyprus & - & $5 / 8$ & 15 & - \\
\hline Latvia & - & 5 & 18 & - \\
\hline Lithuania & - & $5 / 9$ & 18 & - \\
\hline Luxembourg & 3 & $6 / 12$ & 15 & 12 \\
\hline Hungary & - & 5 & 20 & - \\
\hline Malta & - & 5 & 18 & - \\
\hline Netherlands & - & 6 & 19 & - \\
\hline Austria & - & 10 & 20 & 12 \\
\hline Poland & 3 & 7 & 22 & - \\
\hline Portugal & - & $5 / 12$ & 21 & 12 \\
\hline Romania & & 9 & 19 & \\
\hline Slovenia & - & 8.5 & 20 & - \\
\hline Slovakia & - & 10 & 19 & - \\
\hline Finland & - & $8 / 17$ & 22 & - \\
\hline Sweden & - & $6 / 12$ & 25 & - \\
\hline United Kingdom & - & 5 & 17.5 & - \\
\hline
\end{tabular}

Source: VAT Rates Applied in the Member States of the European Community, European Commission, Brussels2008 (DOC/2412/2008-EN). 
Some difficulties are also observed in case of harmonising reduced rates. The Directive that outlines the European Union VAT mode ${ }^{10}$ not only stipulates that member countries are allowed to apply one or two reduced rates that are not lower than $5 \%$ but also points to goods and services whose provision may be subject to protectionist VAT rates. The list of the goods and services mentioned above includes, among others, foodstuffs, water, pharmaceuticals, passenger transportation and social housing. Preferences may also be granted to other selected goods of social nature and goods that are related to culture, healthcare and sport. Moreover, the European Union regulations allow member countries to apply transitionally reduced VAT rates in case of services that are highly human labour intensive.

Comparative research into European VAT rates may lead to the conclusion that apart from the countries that extensively use reduced rates (e.g. Cyprus, Poland or Great Britain), there are also some countries where reduced rates are not applied so willingly (e.g. Bulgaria, Denmark or Slovakia). Numerous countries managed to negotiate the right to introduce solutions that are different than those imposed by the European Union directives, i.e. the right to apply rates that are lower than $5 \%$, to use more than two reduced rates or to protect other goods than those listed in a particular directive. For instance, in some countries (Belgium, Denmark, Finland, Ireland, Poland or Great Britain) the $0 \%$ VAT rate is applied in case of daily newspapers, other magazines or books. Despite temporary nature of all these exceptions, there is less interest of countries involved in prolonging application of the exceptions in question. A good example is provided by the fact that in 2006 the right to apply reduced rates in case of five categories of human labour intensive services (including, e.g., redecoration of flats, hairdressing or household care) was prolonged till $2010^{11}$. This privilege was used by nine countries of the 'old' European Union, i.e. Belgium, France, Greece, Spain, Holland, Luxembourg, Portugal, Great Britain and Italy. Other member countries are also entitled to enjoy the preference discussed. However, they have to obtain the Council's permission to do so.

Comparing Polish solutions related to VAT rates with those binding in other countries of the European Union, it should be generally stated that the standard rate applied in Poland is extremely high. Simultaneously, the subject scope of applying reduced rates is really wide. In Poland the standard rate was set on the level of $22 \%$ in compliance with the European Union requirements. The $7 \%$ reduced rate was introduced as well. At the same time, as a result of pre-accession negotiations, Polish authorities were granted the right to apply transitional preferential rates that amounted to $0 \%$ and $3 \%$, i.e. they were lower than the rates permitted by the European

10 Directive of the Council 2006/112/EC of 28 November 2006 on the common system of VAT (EC Official Journal 2006, L. 347).

11 L. Oręziak, Konkurencyjność podatkowa i harmonizacja podatków w ramach Unii Europejskiej. Implikacje dla Polski, Warsaw, 2007, pp. 151-165. 
Harmonisation of Vat Rates in the European Union Countries...

Union regulations. Furthermore, Poland was also entitled to apply a reduced rate in the scope that was not provided for by the directive (see Table 2 that demonstrates the major scope of applying reduced VAT rates).

Table 2. The scope of applying reduced VAT rates in Poland

\begin{tabular}{|c|c|c|}
\hline \multirow{2}{*}{ Rate } & \multicolumn{2}{|l|}{ The scope of application } \\
\hline & subject & time \\
\hline $7 \%$ & $\begin{array}{l}\text { - goods and services (groups of goods and services) listed in the } \\
\text { Appendix No. } 3 \text { of the Act including some foodstuffs, chemical } \\
\text { products, healthcare related products, transportation services or } \\
\text { culture and sport related services; } \\
\text { - goods and services listed in the Appendix No. } 1 \text { of the Decree } \\
\text { including some foodstuffs; } \\
\text { - some fertilisers and fodder. }\end{array}$ & indefinite \\
\hline $7 \%$ & - catering services (with exceptions) & till 31.12.2010 \\
\hline $7 \%$ & $\begin{array}{l}\text { - construction and assembly related works along with housing } \\
\text { maintenance; } \\
\text { - housing related buildings or their parts excluding business } \\
\text { establishments. }\end{array}$ & till 31.12.2010 \\
\hline $7 \%$ & $\begin{array}{l}\text { - services related to repair of bicycle, footwear and other leather } \\
\text { products, clothing and textiles for personal use, hairdressing. }\end{array}$ & till 31.12.2010 \\
\hline $3 \%$ & $\begin{array}{l}\text { - goods and services (groups of goods and services) listed in the } \\
\text { Appendix } 6 \text { of the Act including unprocessed and lowly processed } \\
\text { agricultural produce. }\end{array}$ & till 31.12.2010 \\
\hline $0 \%$ & - books and specialised magazines & till 31.12.2010 \\
\hline
\end{tabular}

Source: Own elaboration on the basis of the Act of 11 March 2004 on Goods and Services Tax (Journal of Laws - Dz. U. No. 54, item 535, with subsequent changes), Ministry of Finance Decree of 27 April 2004 on execution of certain provisions of Goods and Services Tax Act (Journal of Laws - Dz. U. No. 97, item 970, with subsequent changes).

Transitional period for some preferences expired at the end of 2007 and in case of the $3 \%$ rate on the $30^{\text {th }}$ of April 2008. As a result of further negotiations, Polish authorities were granted the right to prolong the transitional period till the end of 2010, which was manifested in the change of the Directive 2006/112 $2^{12}$.

Since 1994 - every two years - the European Union authorities have been making an overview of the scope of reduced rates. Experience obtained so far has clearly shown that VAT preferential sectors are strongly determined by the internal policies of public authorities in a particular country. Some decrease in diversification

12 Directive of the Council 2007/75/EC of 20 December 2007 amending the Directive 2006/112/EC with regard to certain temporary provisions concerning rates of VAT (EU Official Journal 2007, L. 346). 
of reduced rates in particular member countries will be labour intensive and quite complicated. However, some efforts have already been undertaken in order to eventually eliminate reduced VAT rates in all member countries since 2011. The Commission formulated such a proposal in July 2007 on the basis of the special report that analysed economic effects of the rates in question thoroughly ${ }^{13}$.

\section{Conclusions}

The level of harmonisation of VAT rates including both standard and reduced rates is low in the European Union member countries. There is considerable diversification of standard rates and in case of reduced rates and their level, volume and scope, the diversification in question is even higher. From a perspective of desired effectiveness of the common market, it is necessary to aim at equalising VAT rates in particular European Union countries, which is definitely not going to be easy. VAT takes particular fiscal functions that are diversified in particular countries. Therefore, while considering harmonisation of the VAT rates, it is necessary to pay much attention to economic results of the harmonisation in question. In countries where the highest VAT rates are in use, some reduction in the very rates would mean some decrease in budget revenues, which would simultaneously involve a necessity to look for supplementary sources to support the budget financially - mainly by means of increasing other fiscal burdens. On the other hand, in countries that apply low rates some increase in the rates in question would result in some increase in the level of prices.

VAT harmonisation has always been and still is a painstaking, labour intensive and sophisticated process. Further developments in the harmonisation will definitely be difficult, which mainly results from the European Union enlargement of 2004 and 2007 when so many new countries entered the Community. The European Union is now characterised by a more complex fiscal system since fiscal systems of particular countries and their internal functions are highly diversified. The principle of being unanimous while making the Community fiscal law is more difficult to follow in a group of twenty seven countries as compared to the 'old' fifteen. Directives do not always turn out to be effective regulations while trying to reach harmonisation related objectives.

Fiscal harmonisation including VAT related issues is obviously not supported by local authorities' inclinations to retain fiscal autonomy. A tax is one of the most important instruments that are used by public authorities while realising predefined economic and social goals. Fiscal suggestions are also attractive elements

VAT Reduced Rates, European Commission, Brussels, 5.07.2007 (IP / 07 /1017), (http://europa.eu/taxation). 
of a political game. That is why there are better perspectives for harmonising more detailed solutions than those of elemental nature including such transparent solutions like tax rates. Development that involves equalising VAT rates is one of the 'critical points' of harmonisation.

Further European Union harmonisation of VAT rates aims at liquidating reduced rates before 2010. If such harmonisation succeeds, it will strongly affect Poland where the scope of applying reduced rates is really wide. In the aspect of anticipated changes within the system of the European Union VAT rates, it is already possible to consider a variant that would be some alternative to the present one, i.e. a very high standard rate and a complex system of preferences should be replaced with a lower standard rate and limited protectionism. On the one hand, such a solution would contribute to simplification of the VAT system (among other with reference to classification related issues). On the other hand, the solution in question would mean some increase in prices in case of many goods and services of the first need. The very issue of reducing standard rates remains still open since it requires some more sophisticated assessments. The VAT perspective is not sufficient here. VAT related receipts are a derivative of consumption related expenditures - they increase when consumption rises. Therefore, potential decreases in standard VAT rates should also be evaluated in connection with forecasts concerning a particular economic situation. The tax in question is a fundamental source of the State's budget revenues in Poland. That is why, while discussing the problem of rates, it is impossible to forget about the problem of budget equilibrium along with effectiveness and policy related to other taxes including income taxes in particular. 


\section{Streszczenie}

Referat koncertuje się na problematyce harmonizacji podatku od wartości dodanej (VAT) - jednym z najważniejszych w Unii Europejskiej. W jego treści uwzględniono stawki tego podatku, porównano różne rozwiązania stosowane w poszczególnych krajach (szczególnie w Polsce), jak również przedstawiono planowane kierunki zmian i oczekiwanych rezultatów w zakresie standaryzacji stawek. 